\title{
NOTES
}

\section{FOUR LETTERS ABOUT WHITMAN IN THE ANGELI-DENNIS PAPERS}

The Rossetti family archive at the University of British Columbia Library, formed by William Michael Rossetti but now called the Angeli-Dennis Papers after his daughter and granddaughter, Helen Rossetti Angeli (1879-1969) and Imogene Dennis (1904-1993), ${ }^{1}$ must have contained substantial Whitman material at the date of Rossetti's death in 1919. Whitman's letters to Rossetti were probably sold to eager American collectors by his heirs shortly after Rossetti's death, ${ }^{2}$ as one suspects were the Philadelphia letters of Anne Gilchrist to Rossetti, though the latter have failed to surface in a public collection. Despite these sales, however, this comparatively unknown archive remains a valuable source of information about the promotion of Whitman's reputation in Victorian England and about several visitors to Whitman who described their visits to Rossetti. As Whitman's first British editor in Poems by Walt Whitman (1868), and as the prime mover in the 1876 and 1885 British subscriptions for the benefit of the poet, Rossetti's was for a quarter of a century the British name most readily associated with Whitman's. Whitman is a frequent subject of discussion in letters to Rossetti from the publisher of his Whitman edition, John Camden Hotten, as well as Moncure Conway, Charles Aldrich, ${ }^{3}$ J.W. Wallace, Herbert Gilchrist, who accompanied his mother to the United States and painted Whitman's portrait, Anne Gilchrist herself in half a dozen letters which remain in the collection, and a host of lesser-known figures. (Rossetti's largely unpublished diaries in the collection also abound in references to Whitman.) $)^{4}$ This note concerns two of the lesser-known correspondents, one American and one British, who reported on visits to Whitman and interested themselves in his welfare: Joseph B. Marvin and Charles Rowley. Marvin's relationship with Whitman has been documented in Edwin H. Miller's Walt Whitman, The Correspondence, ${ }^{5}$ though most of the poet's letters to him are untraced, but Rowley's 1887 visit to Whitman has received only passing mention. ${ }^{6}$

The two Marvin letters to Rossetti in the collection have a three-fold interest: in addition to the always welcome chance to hear the voice of a man whom Whitman in 1875 called "an old and valued friend," " but who is otherwise a shadowy figure, the letters provide a sharper account of Whitman's negative response to Longfellow than the one found in Horace Traubel's record of Whitman's conversations ${ }^{8}$ and contain two brief extracts from one of Whitman's lost letters to Marvin. Marvin's first letter, November 11, 1876, was written about a year after his visit to London, when, carrying a letter of introduction from Whitman, he dined at Rossetti's house in Euston Square, Bloomsbury. ${ }^{9}$ An employee of the Treasury Department in Washington, Marvin was in London on government business, but it was undoubtedly his earlier 
association with the New England journal the Radical, of which he was coeditor from 1866 to 1867 , that determined the dinner guests assembled by Rossetti: Joseph Knight, the editor of the Sunday Times; Justin McCarthy, a leader writer on the Daily News; the painter and republican, Ford Madox Brown; the Victorian feminist, Mathilde Blind, who was the stepdaughter of the German revolutionist Karl Blind; and Anne Gilchrist, all of whom would have shared the anti-establishment social and religious views espoused in the Radical. Following several remarks on a paper of his on Whitman which Rossetti had encouraged him to submit to an English journal (for the publication of which, see Marvin's second letter), and on the first Whitman subscription then underway in England, Marvin describes recent visits to Whitman and Anne Gilchrist, who had travelled to the United States a couple of months earlier in her tragic pursuit of the poet.

\section{Washington City. U.S. \\ November 11, 1876}

Dear Sir,

... I visited Philadelphia last month and spent a few hours with Whitman, and also with Mrs. Gilchrist and her family. I found the Poet a little better in health, and quite hopeful, believing that a complete change in his life-a sea-voyage or something of that sort would restore him to strength. Since returning home I have heard that he was not quite so well, but that it was because he had attempted too much in the way of visiting, he having been in the Country with some farmer friends for some weeks. ${ }^{10}$

Mrs. Gilchrist seemed very happy, and satisfied with their adopted residence. She was about to move into a new house, and was full of expectation. I warned her that moving into a new house, she would have all sorts of troubles for some months, and I learn that her trials have already begun: just in what form I don't know. Whitman goes very often to see the Gilchrists and spoke of them to me in the highest praise, as of course he must do of such charming people as they are. I hope to have Mrs. Gilchrist to visit my family here sometime.

Whitman told me Longfellow had been to see him, ${ }^{11}$ being in Philadelphia, and persuaded no doubt to do so by his friends. Whitman did not like him. Said he looked very well, but when he talked he was dapper and dainty and effeminate. He was to Whitman like the lord whose wife was advised to keep him dressed well but never let him open his mouth. I thought I discovered that Whitman felt a little more wrath than he has ever shown before, on account of the treatment he has had from the literary men of this country....

I am cordially yours

J.B. Marvin.

Marvin's second letter, May 8, 1877, which contains the extracts from an untraced Whitman letter, ${ }^{12}$ is mostly about the poet's often mooted but never undertaken visit to England, and the projected publication of Marvin's Whitman paper in a new American journal, the Radical Review.

\section{Dear Mr. Rossetti}

Washington City. U.S.

May 8, 1877

... I have received letters, during the last week, from our friends Mr. Whitman and Mrs. Gilchrist. You will be glad to learn that the Poet is in better health, and will, if it can be arranged, make the voyage to England. He says: "I am charging about a good 
deal, which is a good sign of my probably improved health (but bad enough at that), only I feel undoubtedly cheery and buoyant in mind, which is the main matter." Referring to my suggestion that possibly the Secretary of our Navy ${ }^{13}$ could be induced to give him a passage to England in a Government vessel, he says: "I should like well to make that round trip to Europe if it could be managed. The Doctor thinks it is just what I need." I wish his favourable view of the project had come earlier, as the former Secretary of the Navy knew the Poet, and I do not know if the present Secretary knows him or will interest himself in the matter if he does. I shall move in the matter, however. Have even considered the propriety of addressing a letter to your Mr. Inman, ${ }^{14}$ through a friend in England who knows him intimately. Unfortunately I found that my English friend had never heard of Whitman. If you have any suggestion to make in the matter let me have it.

My paper about the Poet is to appear in the second number of a new magazine that is to be published in New Bedford, Massachusetts, entitled the Radical Review. ${ }^{15}$ The first number will be out in a few days, the second in August, it being a quarterly. It will be a liberal journal, but, possibly, too didactic, and polemical, though I hope it may better represent our literature, or rather indicate what our literature ought to be, better than any of our monthlies. ...

\section{I remain, Yours, J.B. Marvin}

The earlier of the second group of (again) two letters, written by the Manchester Ruskinian social reformer, Charles Rowley, ${ }^{16}$ offers yet another account of Whitman's living conditions at Mickle Street, Camden, and of the warm personal welcome he extended to visitors, which confirms what other visitors have reported, but adds sufficient circumstantial detail about the house, housekeeper, and visits of a "poor old woman" and a "young . . . telegraph clerk" to make the paragraph a powerful, roughedged vignette of the aging poet. Of particular interest in both letters is Rowley's attempt, unfortunately brief, to understand Whitman's social and political significance. In the first letter, April 7,1887 , he places him in the context of the Lancashire radical, Samuel Bamford, who was sentenced to twelve months imprisonment for leading a contingent to the political reform meeting in St. Peter's Fields, Manchester in 1819 , and addressing the crowd of 80,000 . Rowley's father, who attended the meeting, was an old friend of Bamford, from whom the young Rowley heard stirring accounts of the Peterloo massacre which broke up the meeting. In the same letter Rowley expresses his admiration for Terence V. Powderly, the leader of the American Knights of Labour workers' union, and it is Powderly along with the followers of Henry George's economic principles who are credited, in the second letter, with "putting Whitman's ideas . . . before the public."

\footnotetext{
Philadelphia,

April 7, 1887

Dear Rossetti,

Yesterday I saw Walt Whitman and had a most interesting time with him. This City is a very fine one as a "City of Homes," as they call it, but after the solid simplicity of their domestic architecture there is little of value though much of weight and marble magnificence. Across the Delaware is Camden \& why it should be there is a puzzle for you can't see what its right of existence is. Mickle Street is simply two rows of rather
} 
poor looking wooden frame houses which after the solidity of the City marbles look decidedly mean. The house I want is detached \& a very comely middle aged woman ${ }^{17}$ tells you that Walt Whitman is in. He sits in a little 12 feet by 10 room, floor all covered with newspapers, magazines \& books, he himself, a real G.O.M., ${ }^{18}$ in an arm chair his feet towards the stove is reading. At once he is alive to the visitor, and in giving him your letter \& announcing myself from you I am at home. Nothing can exceed his thankful expressions of affection and gratitude to you especially as representing what English friends have done for him. I was with him for four hours and we had good talks about all kinds of things. I had dinner with him in the little kitchen \& we were merry enough. A poor old woman came in and she was in trouble. She had broken a $1 / 4$ dollar dish $\&$ didn't know what to do. I provided the dish and Whitman gave her some dinner. A young fellow, a telegraph clerk, ${ }^{19}$ came in as we had finished \& had some food. He is deeply attached to Whitman, is here for surgical treatment, \& lives some 15 miles off. It was very touching to see him affectionately kiss Whitman as we left. I am sorry to tell you that the pension has never been awarded, so Whitman is just as dependent on friends as ever. In the fearful rush of American life he is of course left high and dry \& even cultivated Americans smile at ones [sic] enthusiasm for such a man. The turmoil of both body and mind here is past belief and I told Whitman that my time with him had been my first experience of absolute repose since I had come to the States. His "aloofness," and yet his perfect sympathy with you as a human being are very remarkable. There is no hope of his coming to England. He looks very hearty though and reminds me of old Sam Bamford our Lancashire veteran postwar reformer. Later in the day I saw Powderly the head of the Knights of Labour movement. He is a very remarkable man-able, calm, resolute in the great work which is already revolutionizing American life. I also lingered in the room where the Declaration of Independence was signed. So you see my experience is varied and deeply interesting. . . .

\title{
Yours truly \\ Charles Rowley
}

\author{
The Glen, \\ Harpurhey, \\ [Lancashire], \\ May 22, 1887
}

Dear Rossetti,

As to Walt Whitman's pension I learnt from him that "the bill" authorizing it had not been reached. It was lost in the process in Congress ${ }^{20}$ which is something like our massacre of the innocents at the end of a session. Whether there is sufficient interest in Whitman among Congress men to revive such a bill remains to be seen. Whitman himself has no suggestion to offer. I told him that his English lovers were prepared to help him in any way he could suggest. I wish there was someway of touching yet more the conscience of the best Americans to care for their greatest men. I fancy something may be done and the fine reception he got in New York about six weeks since is a good sign and should have brought in a pile of dollars. ${ }^{21}$

I wish I could write I would devote myself to the work of preaching Whitman's Gospel to dunces. Mrs. Gilchrist's papers are delightful and most useful and suggestive. ${ }^{22}$ Do you know I think the Knights-of-Labour \& the Georgites are putting Whitman's ideas in many ways before the public. . . .

\section{Yours truly, Charles Rowley}

The references in these letters to Bamford, Powderly, and the "Georgites" make one wish for a fuller account of Rowley's visit than we are ever likely to get. In his autobiography, Fifty Years Work Without Wages, he gives numerous 
details of his early life and friendships, some of which he was bound to have shared with Whitman, who told Herbert Gilchrist on April 7, 1887, that he "had a good visit from Charles Rowley of Manchester yesterday." 23 Rowley liked to dwell on his youthful "working at the bench in a developing workshop," his "rampaging in the streets of Ancoats, and chumming with hooligans," and the pleasure he took in listening to William Morris's political speeches, especially when after a speech on "Wealth and Riches" Morris would patiently answer the questions of inarticulate working men but, by contrast, would show only "vehemence when flooring some well-to-do jabberer, often a mere rentier, who assumed he was advocating robbery." 24 Whitman's sympathetic response to such stories can easily be imagined. After Rowley's return to England, he dined with William Rossetti at Euston Square on July 1, 1887, but Rossetti's entry in his diary recording the dinner is short on details of Rowley's account of his Whitman visit: "Rowley also dined with us. He seems to have been deeply impressed by his recent interview with Whitman: says it was like spending an hour with Socrates."25

\section{University of Calgary}

Roger Peattie

\section{NOTES}

1 The archive remained in the possession of Mrs. Helen Rossetti Angeli until the late 1960s, when it was acquired by the University of British Columbia Library. For a period in the 1950s and early 1960 s part of the archive was on loan to the Bodleian Library, Oxford.

2 Nothing in Rossetti's correspondence or diaries suggests that he himself disposed of any of Whitman's letters. Of the 28 Whitman to Rossetti letters published in Edwin H. Miller, ed., Walt Whitman, The Correspondence, 5 vols. (New York: New York University Press, 1961-1969), six are printed from drafts or transcripts; the manuscripts of the remaining letters are located in six different collections.

3 For Aldrich's letters to Rossetti concerning Whitman, see Roger W. Peattie, "Whitman, Charles Aldrich and W.M. Rossetti in 1885: Background to the Whitman Subscription," American Literature 58 (October 1986), 413-421.

4 Some of this material was used in the annotation of Selected Letters of William Michael Rossetti, ed. Roger W. Peattie (University Park: Penn State University Press, 1990).

5 See Corr., vols. 2 to 5, especially $2: 317 \mathrm{n}$.

6 Corr., 4:80.

7. Corr., 5:302.

8 Horace Traubel, With Walt Whitman in Camden (New York: Century Co., 1905), 1:130: "I asked W. about L.'s port and manners. W. said: 'His manners were stately, conventional — all right but all careful.' Was his conversation striking? 'Not at all-he did not branch out or attract." "'

9 Selected Letters of W. M. Rossetti, 332-333. For Whitman's letter of introduction, see Corr., 5:302. 
10 Whitman stayed with the tenant farmers, George and Susan Stafford, at Laurel Springs near Camden, from October 10-19.

11 For Longfellow's visit, see Corr., 4:52n.

12 Miller's “Check List of Whitman's Lost Letters" for 1877 does not include a letter to Marvin earlier than December 6 (3:431).

13 George Robeson (1829-1897) was Secretary of the Navy, 1869-1877 in the first and second Administrations of Ulysses Grant. During the 1850s he practised law in Camden, and was appointed Prosecuting Attorney for Camden County in 1858. Richard W. Thompson (1809-1900) succeeded him as Secretary of the Navy, 1877-1880 in the Administration of Rutherford Hayes.

14 Probably William Inman (1825-1881), founder of the Liverpool, New York and Philadelphia Steamship Co., usually called the Inman line.

15 "Walt Whitman," 1 (August 1877), 224-259.

16 For Rowley, see his Fifty Years Work Without Wages (London: Hodder and Stoughton, 1911), and the long obituary, "Charles Rowley, 'Rowley of Ancoats'," Manchester Guardian (September 7, 1933), 4.

17 Mrs. Mary Davis, who became Whitman's housekeeper on February 24, 1885.

18 Grand Old Man.

19 Not identified.

20 The private member's bill to award Whitman a $\$ 25$ a month pension in recognition of his hospital work during the Civil War was introduced in the House of Representatives by the Massachusetts Congressman, Henry B. Lovering, presumably before Whitman's letter to Sylvester Baxter dissenting from the move (CORR. 4:56). Biographers' accounts of the bill differ from one another, and from the explanation for its failure that Whitman gave Rowley. Gay Wilson Allen writes that the bill "was reported favorably to the House and would probably have passed if Whitman, when he heard of it, had not replied that he was not a dependent and did not wish to receive a pension, whereupon the bill was quietly dropped." (The Solitary Singer, A Critical Biography of Walt Whitman [New York: New York University Press, 1967], 524-525). Justin Kaplan attributes the failure of the bill to the opposition of Colonel Thomas Wentworth Higginson, whose hatred of Whitman was intense (Walt Whitman, A Life [New York: Simon and Schuster, 1980], 24). Some combination of the three accounts seems closest to the truth. Despite Whitman's initial disinclination, he informed W.S. Kennedy on January 26,1887 that he had "finally concluded to let the thing take its course" (Corr., 4:66). However, Higginson's attack in Harper's Bazar (especially his charge that Whitman was "a man of conspicuously fine physique, but who deliberately preferred service in the hospitals rather than in the field") (Corr., 4:86-87n), very likely soured and undermined the whole effort.

21 Whitman lectured in Madison Square Theatre before a large audience, which included Mark Twain and J.R. Lowell. Andrew Carnegie donated $\$ 350$, bringing the total raised by the lecture to $\$ 600$ (Allen, 525).

22 In addition to her celebrated article, "A Woman's Estimate of Walt Whitman" (Radical 7 [May 1870], 345-379), Mrs. Gilchrist had recently published "A Confession of Faith," To-Day n.s. 3 (June 1885), 269-284.

23 Corr., 4:80. 
24 Fifty Years Work Without Wages, 7, 9, 131.

25 Unpublished diary, Angeli-Dennis Papers.

\section{GRACE ELLERY CHANNING AND THE WHITMAN CALENDAR}

In documenting Whitman's brief time of celebrity in 1887-1888 and the commercialization of his name that accompanied it (e.g., the Walt Whitman cigar), David Reynolds in Walt Whitman's America makes reference to Grace Ellery Channing, "a Pasadena woman," who, he says, requested permission "to publish a Walt Whitman calendar, with illustrated excerpts from his poems." Not certain as to whether or not the calendar ever appeared, Reynolds moves on to yet another example, the Whitman tree dedicated by public school students in Bath, Maine in 1889. Grace Channing's connections to the world of nineteenth-century literature and to Whitman are deserving of greater acknowledgement than this single passing, and not even footnoted, reference in Reynolds's book.

Grace Ellery Channing (1862-1937) was the daughter of William F. Channing, medical doctor, inventor, and son of the highly esteemed Unitarian clergyman, William Ellery Channing, whose writings greatly influenced the young Ralph Waldo Emerson. Her mother was Mary Tarr Channing, sister of Ellen Tarr who became the wife of Whitman's famous champion, William Douglas O'Connor. Grace's numerous New England relatives included cousin Thomas Wentworth Higginson. As a young girl growing up in Providence, Rhode Island, Grace Channing became great friends with Charlotte Perkins Gilman, whose family was also among New England's most illustrious and included her grandfather, Lyman Beecher, and her great aunt Harriet Beecher Stowe.

Fostered by their mutual background and a shared longing for literary careers, the bonds between Grace and Charlotte grew strong, and in 1885 when Charlotte found herself, soon after the birth of her daughter Katherine, desperately unhappy in her marriage to the artist Walter Stetson, Grace's parents invited her to visit them in their Pasadena, California, home. The Channings had moved to California on the advice of Grace's doctor when her persistent respiratory problems were diagnosed as tuberculosis, and they were pleased to provide help to their daughter's friend and companionship to Grace in her illness. Without the distractions of husband and baby, Charlotte was able to paint a bit, and she and Grace wrote a play. In 1887 when Charlotte, having endured the S. Weir Mitchell treatment of her nervous disorder so dramatically portrayed in her short story "The Yellow Wallpaper," reached a separation agreement with her husband, the Channings rented a small house for her and her daughter very near their Pasadena home. Grace and Charlotte resumed their joint writing ventures, and, when Charlotte's husband came to visit, her parents encouraged him to remain by making a room in their home into a studio where he could work.

Under this arrangement, and with the Channings-especially Grace-actively promoting Walter Stetson's career, Charlotte's emotional life improved 